Cita: Díaz-Díaz, R.; Ramos-Verde, E. J.; García-Manso, J. M.; Valverde-Esteve, T.; Arriaza-

Ardiles, E. (2018). The use of Polar Coordinates in the analysis of motor interaction in football according to the result. Cuadernos de Psicología del Deporte, Vol 19(1), 60-75

\title{
The use of Polar Coordinates in the analysis of motor interaction in football according to the result.
}

\section{El uso de Coordenadas Polares en el análisis de las interacciones motrices en el fútbol en función del resultado.}

\section{O uso de coordenadas polares na análise de interações motoras no futebol com base no resultado.}

Díaz-Díaz, R. ${ }^{1}$, Ramos-Verde, E.J. ${ }^{1}$, García-Manso, J.M. ${ }^{1-2-}$, Valverde-Esteve T. ${ }^{3}$, Arriaza-Ardiles, E. ${ }^{2-4}$

${ }^{1}$ Departamento de Educación Física de la Universidad de Las Palmas de Gran Canaria. España; ${ }^{2}$ Centro de Estudios Avanzados (CEA), Universidad de Playa Ancha, Valparaíso, Chile; ${ }^{3}$ Departamento de enseñanza musical, plástica y expresión corporal de la Universidad de Valencia; ${ }^{4}$ Facultad de Ciencias de la Actividad Física y el Deporte. Universidad de Viña del Mar, Chile.

\begin{abstract}
(150 palabras) (mismo orden que títulos)
The interactions of a Spanish football team of the Second A (Liga 123) (10 official games) are analyzed, evaluating possible behavioral patterns that appear in a regular way in high level football. Observational methodology was used, by Polar Coordinates Analysis, to discover and evaluate the relationships generated between a considered focal behavior and the different conditioned categories, describing behavioral masses among the players. The matches were observed and recorded with an ad hoc observation instrument. The relations of dual character between the players taken as (focal behaviors) right midfielder and forward and the other players (conditioned conducts) were analyzed. The results showed differences in the relationship established based on the outcome of the match.
\end{abstract}

KeyWords: Football, Polar Coordinates, Motor interactions, Offensive play

\section{RESUMEN}

Se analizaron las interacciones de un equipo del fútbol español de la Segunda A (Liga 123) (10 partidos oficiales), evaluando posibles patrones de conducta que aparecen de forma regular en el fútbol de alto nivel. Se utilizó metodología observacional, mediante Análisis de Coordenadas Polares, para descubrir y evaluar las relaciones generadas entre una conducta considerada focal y las distintas categorías condicionadas, describiendo mapas conductuales entre los jugadores. Los partidos fueron observados, y registrados con un instrumento de observación ad hoc. Se analizaron las relaciones de carácter dual entre los jugadores tomados como (conductas focales) medio centro derecho y delantero centro y los demás jugadores (conductas condicionadas). Los resultados muestran diferencias en la relación establecida en función del resultado del partido.

Palabras Clave: Fútbol, Coordenadas Polares, Interacciones motrices, Juego ofensivo. 
The use of Polar Coordinates in the analysis of motor interaction in football according to the result.

\section{RESUMO}

As interações de uma equipa de futebol espanhol do segundo A (Liga 123) (10 jogos oficiais) foram analisadas, avaliando possíveis padrões de comportamento que aparecem regularmente no futebol de alto nível. Foi utilizada uma metodologia observacional, pela Análise de Coordenadas Polares, para descobrir e avaliar as relações geradas entre um comportamento focal considerado e as diferentes categorias condicionadas, descrevendo mapas comportamentais entre os atores. As partidas foram observadas e registadas com um instrumento de observação ad hoc. Foram analisadas as relações de caráter dual entre os jogadores, tomadas como (comportamentos focais) centro médio direito e centro da frente e os outros jogadores (condutas condicionadas). Os resultados mostram diferenças no relacionamento estabelecido com base no resultado da partida.

Palavras chave: futebol, coordenadas polares, interações motoras, jogo ofensivo.

\section{INTRODUCTION}

Football can be classified as a cooperationopposition sport in which players alternate roles of attack (offensive phases) or defence (defensive phases) expressed through technical actions, communication and interaction with their peers and opposition with their rivals. All this while trying to achieve possession of the ball and move it towards the opponent's area and shoot at goal. It must be taken into account that all the actions performed by the players, during both the offensive and defensive phases, respond to the actions carried out by all the participants in the game (Lago \& Anguera, 2002; Barreira, Garganta, Castellano, Machado \& Anguera, 2015; Fernández-Hermógenes, Camerino \& GarcíaAlcaráz, 2017). These behaviours vary in quality, configuration and richness, depending on the level of the players (Sampaio \& Macas, 2012; Castañer et al., 2017), the style of play (Tenga, Holme, Ronglan \& Bahr, 2010 a ; Tenga, Ronglan \& Bahr, $\left.2010^{b}\right)$, the circumstances of each move (Fernández-Navarro, Fradua, Zubillaga, Ford \& Mc Robert, 2016), the time available (SánchezFlores, Martín-González, García-Manso, De Saa \& Arriaza-Ardiles, 2016) and the score (advantage, draw or disadvantage) (Lames \& McGarry, 2007; Lago \& Martin, 2007, Almeida, Duarte, Volossovitch \& Ferreira, 2016). Each circumstance modifies the degree of complexity of the actions and determines the structure of the direct and indirect motor relations that occur during the game (Grehaigne, Bouthier \& David
1997; Blommfield, Polman \& O'Donoghue, 2005). It must also be taken into account that the relationship between players is not always limited to the immediate situation, but rather their behaviour is affected by events that occur in scenarios in which they are not even direct protagonists and that, even so, condition their actions and everything that happens in their immediate environment (Seabra \& Dantas, 2006; Castellano, Álvarez-Pastor \& Blanco-Villaseñor, 2013; Moura, Santana, Vieira, Santiago \& Cunha, 2015). All players interact by forming dynamic structures and complex behaviours that vary in space and time, forming patterns of selforganization that are continually trying to adapt to situations of play (Clemente, Martins, Couceiro, Mendes \& Figuereido, 2014). Such behaviours obey a similar logic to that explained by the black swan theory popularized by the Lebanese mathematician Taleb (2010). For this, it is essential to know those factors that make up the essence and logic of the sport, where the tactical component, the game model and its demands are the first step to train the variables that make up the game. From his understanding, it is possible to identify the needs of the player and the means to teach him the skills that allow him to face and solve the different sporting challenges (Tassi, Rivera \& Morilla, 2018). The reality of football tells us that players must be prepared to face the situations that the game is going to present to them. A game that demands rhythm, intensity, speed, determination, but also control, balance, pause in 
short, understanding of the game. To understand the game, it is necessary to think about the game. We need players who think, who are autonomous, who understand the game and who make decisions for themselves (Ruiz de Oña, 2018).

In any case, not all players have the same importance in the game. The connectivity between the members of each team shows the existence of players who act as an attractor of creation, distribution, intermediation or end of the game (Martín-González et al, 2018). Each of these players generates recurring behaviours that are specific, executed in very particular spaces within the game, which respond to the role that has previously been assigned to each player. Such a singularity contains two important obstacles when it comes to understanding the behaviour of these players during the competition. First of all, it must be kept in mind that the players' behaviour cannot be explained from their personal attributes but requires more complex analyses and interpretations that take into account their relationship with opponents and partners. Secondly, it must be considered that individual actions can develop so-called aggregate effects, which can cause perverse effects to emerge in the players' behaviour that, in turn, can become unrecognized conditions in later situations (Lago \& Anguera, 2002).

Nowadays, few people doubt that there has been a significant change in the methodology used in scientific research in recent decades. These changes are characterized, among other aspects, by the reinforcement of the mechanistic (reductionist) paradigm, giving way to more holistic (ecological) models in which the theory of complexity plays an important role. The emergence of these models puts the emphasis on the analysis of the whole rather than necessarily entering into details about the components of each phenomenon, favouring the variability and evolutionary dynamics that all physical, social or biological systems show. Sports sciences, especially in high-level performance, have also been affected by these methodological changes, leading to a permanent and exponential evolution stimulated by an approach that seeks to integrate the development and use of different technologies from multidisciplinary paradigms (Glazier \& Robins, 2013). In team sports, one of the most widely used tools has been Observational Methods (Anguera \& Hernández-Mendo, 2015). The different analysis techniques used in this proposal include Polar Coordinates Analysis (Sackett, 1980). This mathematical technique responds to a double methodological strategy: the reduction of data and the vectorial representation of the network of links or relationships established between the different categories selected in an $a d$ hoc system prepared for recording the flow of behaviour observed in the game play during a soccer match. This technique has become increasingly relevant in the world of sports, finding its place in various disciplines and, very often, in football (Anguera \& Hernández-Mendo, 2015; Castañer et al., 2017), and also in others sports (Castellano \& Hernández-Mendo, 2002; Echeazarra, Castellano, Usabiaga \& HernándezMendo, 2015; López-López, Menescardi, Estevan, Falcó \& Hernández-Mendo, 2015; Morillo-Baro, Reigal \& Hernández-Mendo, 2015; Sousa, Prudente, Sequeira, López-López \& HernándezMendo, 2015; Riveiro-Bozada et al.,2016; Morillo, Reigal, Hernández-Mendo, Montaña,\& Morales-Sánchez, 2017; Navarro, Morillo, Reigal, \& Hernández-Mendo, 2018).

\section{MATERIAL \& METHODS}

To understand players' behaviour in sport like Football, Observational Methodology has been a usefull tool from last years. This methodogy itself has got some differents tecniques, in wich we cand find the Coordinates Polar (Sacket, 1980), modified later by Anguera (1997), so it can offer posibilities to estimate the kind of relationship between a focal conduct and the rest of the behaviours than are included in the taxonomic system. (Hernández-Mendo \& Anguera, 1999; Castellano \& Hernández-Mendo, 2002; Castellano \& Hernández-Mendo, 2003; Castellano, Hernández-Mendo, Morales \& Anguera, 2007; Perea, Castellano, Alday \& Hernández-Mendo, 
The use of Polar Coordinates in the analysis of motor interaction in football according to the result.

2012; Anguera, Blanco-Villaseñor, HernándezMendo \& Losada, 2011).

The discriminant criterion used to select these players was their participation in tecnichal/tactical actions that can be considered most specific to each evaluated position (passes or shots at goal).

The objective of this study is to analyze the characteristics of the interactions presented by two players that we consider to be most representative of U.D. Las Palmas in the Second Division A (Liga 123) (right midfielder and centre forward), during the 2008-2009 season, when the outcome of the game changes (won or not won). The discriminant criterion used to select these players was their participation in technical/tactical actions that can be considered most specific to each evaluated position (passes or shots at goal). We have divided the results into two groups of matches, depending on whether the local team won the match (4 matches) or did not win (5 drawn and 1 lost matches), looking for interactions and cooperative relationships that occur between players.

\section{Study Design}

The Polar Coordinates, created by Sacket (1980), modified later by Anguera (1997), responds to a double data reduction strategy and seeks a vector representation of the complex network of interrelationships established between the different categories that constitute our study.

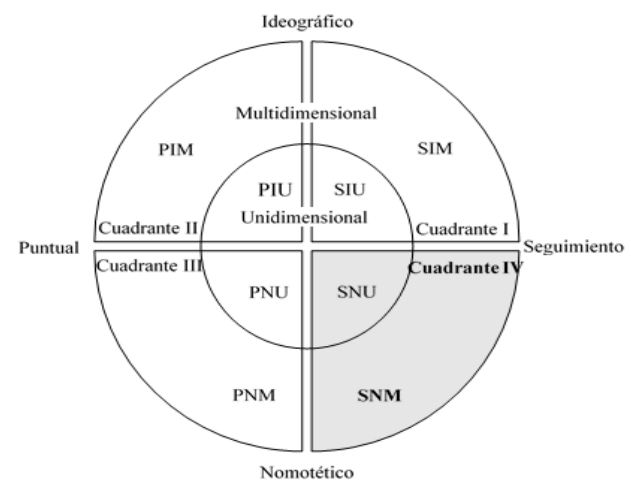

Figure 1. Graphic representation of the eight observational designs, from the superposition of the Units of the study criteria (represented by the vertical diameter), Temporality (represented by the horizontal diameter) and Dimensionality (represented by the concentric circles). There are eight areas, which correspond to the eight observational designs. Adapted from Anguera (2011).

\section{Participants}

Ten official football matches were analyzed, corresponding to matches played by a team in the Spanish Second Division A, in which they played as the home team. The players that we analyzed were the right midfielder (RMF) $(12.5 \%$ of the passes made by the team) and the centre forward (FC) $(22.44 \%$ of the shots at goal executed by the team), as they are the players that showed greatest participation in actions relating to the creation and completion of play (Table 1).

Table 1. Shows the frequency $(\mathrm{N})$ and the percentage (\%) of actions (passing, dribbling, possession, clearance, recovery and shots) performed by each player of the analyzed team (local team) in the 10 games evaluated.

\begin{tabular}{|c|c|c|c|c|c|c|c|c|c|c|c|c|}
\hline \multirow[t]{2}{*}{ Player } & \multicolumn{2}{|c|}{ Passing } & \multicolumn{2}{|c|}{ Dribbling } & \multicolumn{2}{|c|}{ Possession } & \multicolumn{2}{|c|}{ Clearance } & \multicolumn{2}{|c|}{ Recovery } & \multicolumn{2}{|c|}{ Shots } \\
\hline & $\mathrm{N}$ & $\%$ & $\mathrm{~N}$ & $\%$ & $\mathrm{~N}$ & $\%$ & $\mathrm{~N}$ & $\%$ & $\mathrm{~N}$ & $\%$ & $\mathrm{~N}$ & $\%$ \\
\hline GKE & 187 & 6.3 & 0 & 0 & 48 & 3.5 & 29 & 6.6 & 103 & 15.3 & 0 & 0 \\
\hline $\mathrm{RB}$ & 272 & 9.2 & 5 & 1.7 & 96 & 7.0 & 76 & 17.2 & 83 & 12,3 & 8 & 5.3 \\
\hline LB & 337 & 11.4 & 12 & 4.0 & 125 & 9.1 & 66 & 14.9 & 54 & 8.0 & 6 & 4.0 \\
\hline $\mathrm{RCB}$ & 210 & 7.1 & 3.0 & 1.0 & 67 & 4.9 & 69 & 15.6 & 74 & 11.0 & 2 & 1.3 \\
\hline $\mathrm{CI}$ & 248 & 8.4 & 1.0 & 0.3 & 60 & 4.4 & 63 & 14.2 & 79 & 11.7 & 3,0 & 2.0 \\
\hline RMF & 371 & 12.5 & 37 & 12.4 & 162 & 11.8 & 38 & 8.6 & 70 & 10.4 & 21 & 13.8 \\
\hline LMF & 364 & 12.3 & 22 & 7.4 & 155 & 11.3 & 36 & 8.1 & 87 & 12.9 & 14 & 9.2 \\
\hline RW & 279 & 9.4 & 59 & 19.8 & 211 & 15.3 & 21 & 4.7 & 34 & 5.0 & 28 & 18.4 \\
\hline LW & 249 & 8.4 & 66 & 22.2 & 198 & 14.4 & 25 & 5.6 & 50 & 7.4 & 24 & 15.8 \\
\hline SS & 271 & 9.1 & 63 & 21.1 & 153 & 11.1 & 12 & 2.7 & 27 & 4.0 & 12 & 7.9 \\
\hline$F$ & 178 & 6.0 & 30 & 1.1 & 103 & 7.5 & 8.0 & 1.8 & 13 & 1.9 & 34 & 22.4 \\
\hline
\end{tabular}


Díaz-Díaz, R.; Ramos-Verde, E. J.; García-Manso, J. M.; Valverde-Esteve, T.; Arriaza-Ardiles, E.

Note. N: frequency; \%: percentage; GKE: goalkeeper; LB: left-back; RB: right-back; RCB: right centre-back; LCB: left centre-back; RMF: right midfielder; LMF: left midfielder; RW: right winger; LW: left winger; SS: second striker; S: forward

\section{Instruments}

The instrument, prepared was taken of (Díaz-Díaz, Hernández-Moreno y Hernández-Flores, 2016). It was modified the number of criteria analyzed. In our case consists of two criteria (C) with their corresponding categories. C1: Team; C2: Players.

Table 2. Observation instrument with identification of the criteria used and the different categories established.

\begin{tabular}{cccccccc}
\hline CRITERIA & \multicolumn{7}{c}{ CATEGORIES } \\
\hline Team & A & B & & & \\
Player & AGKE & ARB & ALB & ALCB & ARCB & ARMF & \multirow{2}{*}{ ALMF } \\
& ARW & ALW & ASS & AF & & & \\
& & & & & &
\end{tabular}

Note. A (home team), B (away team); AGKE: goalkeeper; ARB: right-back; ALB: left-back; ALCB: left centre-back; ARCB: right centre-back; ARMF: right midfielder; ALMF: left midfielder; ARW: right winger; ALW: left winger; ASS: second striker; AF: forward.

The material used in the coding and recording of the behavioural flow included, first of all, recording the matches in digital format. The LINCE 1.2.1. sports observation and registration software were used (Gabin, Camerino, Anguera \& Castañer, 2012). For the analysis, the Windows version of the sequential analysis program GSEQ v.5.1 (Quera, Bakeman \& Gnisci, 2007) and the application HOISAN 1.2 (Hernández-Mendo, López-López, Castellano, Morales-Sánchez \& Pastrana, 2012) were used to analyze the Polar Coordinates.

\section{Procedure}

In order to prepare and validate the observation instrument, in addition to the review of the literature, the following stages were established: 1) an exploratory observation period was carried out, in which video images of several football matches were watched; 2) the criteria for the instrument were proposed and defined and a list of observed behaviours was drawn up for each of the criteria, in such a way as to make it possible to record the game actions in a synchronous and diachronic manner and allow the internal logic of football to be studied; 3) the experts were asked for their assessment; 4) observation sessions were held to reach agreements regarding the creation of the observation instrument, seeking agreement between observers.

\section{Data analysis}

In order to calculate the quality of the data, once the registration of the first game was completed, the first part of the recording was re-registered. The data were exported to the GSEQ 5.1 computer program to produce an error detection file and calculate the reliability using Cohen's Kappa coefficient (Cohen, 1960), in which all observers exceeded a value of 0.80 for players' category and 1.00 for team's category of the observational instrument. The calculations made with the HOISAN tool are presented below (HernándezMendo et al., 2012).

The results of the analysis show the collected vectorial planes represented by the polar coordinate graphs and the tables containing the values that refer to the quadrant, radius and angle of the vector. Vectors that have a greater length than the radius will be considered significant, since this represents a value greater than $1.96(p<0.05)$.

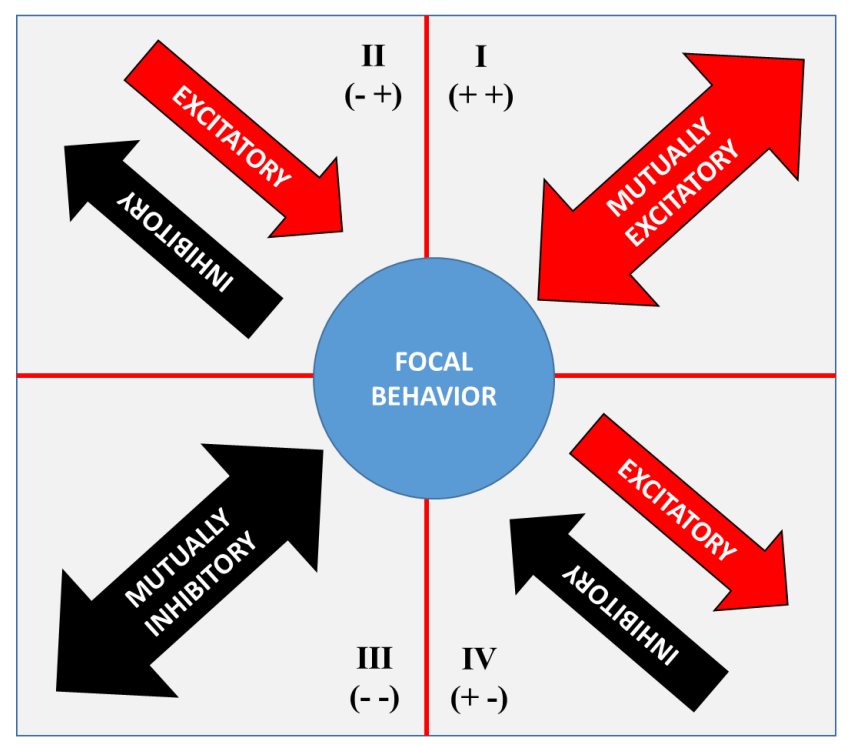


The use of Polar Coordinates in the analysis of motor interaction in football according to the result.

Figure 2. Quadrant I, relationship of mutual activation between the category taken as focal and the conditioned categories; Quadrant II, relationship of activation of the category taken as conditioned behaviour towards the category taken as focal behaviour; Quadrant III, relationship of mutual inhibition between the focal category and conditioned categories; finally, Quadrant IV, relationship of activation of the category taken as focal behaviour towards the category taken as conditioned behaviour.

\section{RESULTS}

The criterion followed is based on the advantage of playing at home. In such circumstances, the home team usually wins the most in the world's main leagues (Pollard \& Pollard, 2005). For this reason, during the game the players try to develop tactical behaviour that allows them to keep possession of the ball and frequently attack the opponent's goal when the score is against them, while they usually give control of the ball to the other team when the team is ahead on the scoreboard (Staufenbiel, Lobinger \& Strausset, 2015). In our opinion, it is therefore the matches won and tied that best reflect what we were aiming to achieve with the use of the polar coordinates technique to study the players' interactions. The fact that possession of the ball decreases in the matches won has already been demonstrated in several studies (Bloomfield et al., 2005; Taylor, Mellalieu, James \& Shearer, 2008; Lago \& Dellal, 2010; Collet, 2012), which emphasize that this possession increases especially in the matches in which the team loses the game. Unfortunately, the team contemplated by this study only lost one of the games they played at home in the period of time that was analyzed, which is why these games were discarded.

Next, we present the behavioural maps and the numerical data for the analysis of polar coordinates of the ARMF and categories of the local team, when they are considered as focal behaviour, differentiating between the matches won and those not won.

\section{Relationship between the right midfielder and other members of the team}

The levels of interaction between the right midfielder and the rest of the team are shown in table 3 (won) and 4 (tied) and figures 3 (won) and 4 (tied).

Table 3. Results of the analysis of polar coordinates for the midfielder of the local team in the matches that ended in victory (ARMF).

\begin{tabular}{lccccc}
\hline Category & Quadrant & $\begin{array}{c}\text { Prospective } \\
\text { Perspective }\end{array}$ & $\begin{array}{c}\text { Retrospective } \\
\text { Perspective }\end{array}$ & Radius & Angle \\
\hline Player (AGKE) & II & -4.24 & 0.19 & $4.25\left(^{*}\right)$ & 177.44 \\
Player (ARB) & II & -0.05 & 3.10 & $3.1\left(^{*}\right)$ & 90.85 \\
Player (ALB) & IV & 1.26 & -1.02 & 1.62 & 320.84 \\
Player (ARCB) & II & -1.72 & 2.21 & $2.8\left(^{*}\right)$ & 127.82 \\
Player (ALCB) & I & 3.64 & 4.32 & $5.65\left(^{*}\right)$ & 49.89 \\
Player (ALMF) & I & 2.14 & 2.32 & $3.16\left(^{*}\right)$ & 47.29 \\
Player (ALW) & II & -0.76 & 3.66 & $3.74\left(^{*}\right)$ & 101.71 \\
Player (ASS) & I & 2.47 & 3.03 & $3.91\left(^{*}\right)$ & 50.84 \\
Player (AF) & IV & 0.46 & -0.66 & 0.81 & 304.93
\end{tabular}

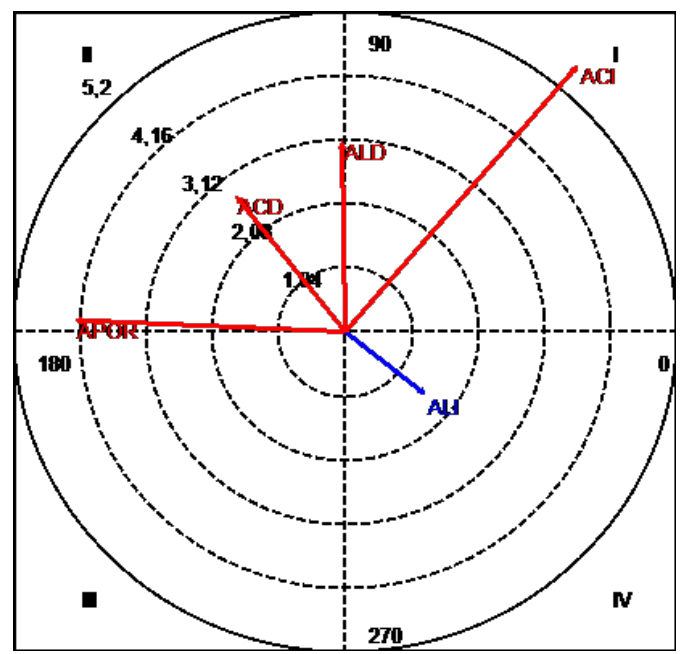


Díaz-Díaz, R.; Ramos-Verde, E. J.; García-Manso, J. M.; Valverde-Esteve, T.; Arriaza-Ardiles, E.

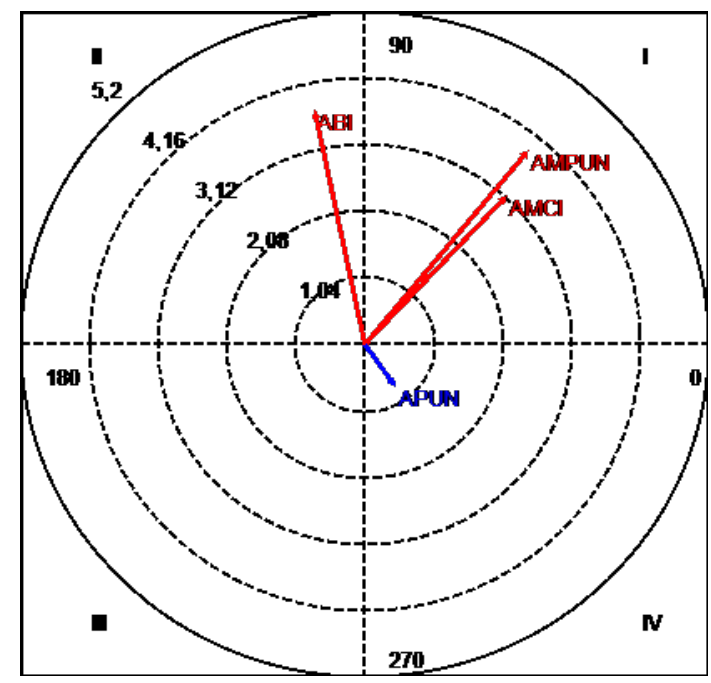

Figure 3. Graphic representation of the vectorial plane when we take the ARMF category as focal behaviour for the other players of the team in the matches that ended in victory. On the left, the type of relationship of the reference player $(\mathrm{ARMF})$ and the most defensive players $(\mathrm{APOR}=$ goalkeeper; $\mathrm{ALI}=$ left-back; $\mathrm{ALD}=$ right-back; $\mathrm{ACD}=$ right centre-back; ACI= left centre-back). On the right, note the relationships with the more attacking positions $(\mathrm{AMCI}=$ left midfielder; $\mathrm{ABD}=$ right winger; $\mathrm{ABI}=$ left winger; AMPUN= second striker; $A P U N=$ striker).

For the focal behaviour of the ARMF player, the players with the most dual interactions (quadrant I) are ALCB, ASS and ALMF. By the length of the radius we can verify the significance of the relationship between the player in question and the ALCB player (both in the retrospective and prospective planes). The ARW, ARCB, AGKE and ALW players appear in quadrant II. No relationship of inhibition is observed. Relationships with the AF and ALB players randomly appear in quadrant IV.
Table 4. Polar coordinates analysis results for the midfielder of the local team in the matches that ended in a draw or lose (ARMF).

\begin{tabular}{lccccc}
\hline Category & Quadrant & $\begin{array}{c}\text { Prospective } \\
\text { Perspective }\end{array}$ & $\begin{array}{c}\text { Retrospective } \\
\text { Perspective }\end{array}$ & Radius & Angle \\
\hline Player (AGKE) & III & $-8,93$ & $-0,90$ & $8,98\left(^{*}\right)$ & 185,74 \\
Player (ARB) & I & 4,33 & 4.13 & $5,99\left(^{*}\right)$ & 43,64 \\
Player (ALB) & I & 2,01 & 1,28 & $2,38\left(^{*}\right)$ & 32,53 \\
Player (ARCB) & I & 1,52 & 6,24 & $6,43\left(^{*}\right)$ & 76,29 \\
Player (ALCB) & II & $-1,54$ & 7,98 & $8,13\left(^{*}\right)$ & 100,94 \\
Player (ALMF) & II & $-0,05$ & 7,76 & $7,76\left(^{*}\right)$ & 90,35 \\
Player (ARW) & I & 12,49 & 3,92 & $13,09\left(^{*}\right)$ & 17,44 \\
Player (ALW) & I & 4,00 & 2,86 & $4,92\left(^{*}\right)$ & 35,52 \\
Player (ASS) & I & 7,30 & 4,57 & $8,61\left(^{*}\right)$ & 32,05 \\
Player (AF) & I & 10,52 & 3,09 & $10,96\left(^{*}\right)$ & 16,35 \\
& & & & &
\end{tabular}

\begin{tabular}{lccccc}
\hline Category & Quadrant & $\begin{array}{c}\text { Prospective } \\
\text { Perspective }\end{array}$ & $\begin{array}{c}\text { Retrospective } \\
\text { Perspective }\end{array}$ & Radius & Angle \\
\hline Player (AGKE) & II & -4.7 & 0.94 & $4.79\left(^{*}\right)$ & 168.74 \\
Player (ARB) & II & -1.57 & 8.75 & $8.89\left(^{*}\right)$ & 100.16 \\
Player (ALB) & I & 2.83 & 1.77 & $3.33\left(^{*}\right)$ & 32.02 \\
Player (ARCB) & II & -1.83 & 3.66 & $4.09\left(^{*}\right)$ & 116.59 \\
Player (ALCB) & II & -2.88 & 4.06 & $4.98\left(^{*}\right)$ & 125.4 \\
Player (ARMF) & I & 3.09 & 10.52 & $10.96\left(^{*}\right)$ & 73.65 \\
Player (ALMF) & II & -0.05 & 4.62 & $4.62\left(^{*}\right)$ & 90.6 \\
Player (ARW) & I & 4.57 & 1.67 & $4.86\left(^{*}\right)$ & 20.03 \\
Player (ALW) & I & 2.13 & 2.14 & $3.03\left(^{*}\right)$ & 45.14 \\
Player (ASS) & I & 1.33 & 0.59 & 1.46 & 23.75 \\
\hline
\end{tabular}

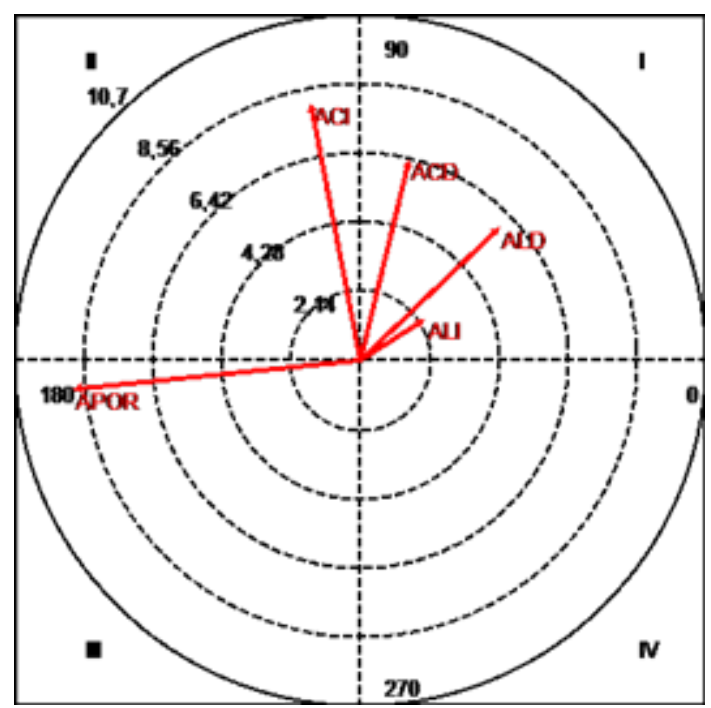


The use of Polar Coordinates in the analysis of motor interaction in football according to the result.

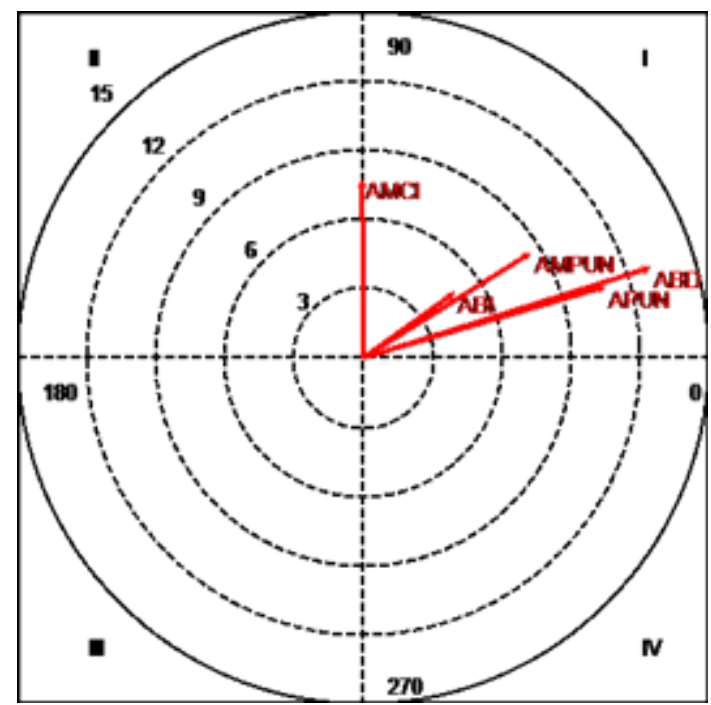

Figure 4. Graphic representation of the vectorial plane when we take the category (ARMF) as focal behaviour for the other players of the team in the matches that ended with a negative result. On the left, the type of relationship of the reference player (ARMF) and the most defensive players (APOR=goalkeeper; $\quad \mathrm{ALI}=$ left-back; $\mathrm{ARB}=$ right-back; $\mathrm{ACD}=$ right centre-back; $\mathrm{ACI}=$ left centre-back). On the right, the relationships with the more attacking positions are shown (left midfielder; right winger; left winger; second striker; forward).

For the focal behaviour of ARMF, we observe mutual activation relationships (quadrant I) with the ALB, ARCB, ARB, ALW, ASS, AF and ARW players. In quadrant II, with activation of the conditioned category towards the focal, we find the ALCB and ALMF players. In the case of the AGKE player, the behaviour is mutually inhibitory. We can verify the ability to associate with different components of the ARMF player's team. In terms of the position they occupy spatially within the team's system of play, the players who occupy the midfield positions have to associate with all the players. In addition, they have the capacity of mutual activation, as observed in the previous graphs. Unlike the analysis of the game that they lost when playing at home, which was analyzed above, there is an improvement in the interaction between the team's two midfielders, who are the most important in the retrospective plane.

Relationships between the centre forward and other members of the team
The interaction levels of the centre forward with the rest of the team are shown in tables 5 (won) and 6 (tied).

\begin{tabular}{lccccc}
\hline Category & Quadrant & $\begin{array}{c}\text { Prospective } \\
\text { Perspective }\end{array}$ & $\begin{array}{c}\text { Retrospective } \\
\text { Perspective }\end{array}$ & Radius & Angle \\
\hline Player (AGKE) & III & -4.16 & -2.31 & $4.76\left(^{*}\right)$ & 209.03 \\
Player (ARB) & II & -2.79 & 3.13 & $4.19\left(^{*}\right)$ & 131.65 \\
Player (ALB) & II & -3.25 & 2.79 & $4.28\left(^{*}\right)$ & 139.31 \\
Player (ARCB) & II & -4.38 & 0.12 & $4.38\left(^{*}\right)$ & 178.42 \\
Player (ALCB) & II & -3.29 & 0.81 & $3.39\left(^{*}\right)$ & 166.08 \\
Player (ARMF) & II & -0.66 & 0.46 & 0.81 & 145.07 \\
Player (ALMF) & II & -1.49 & 5.42 & $5.62\left(^{*}\right)$ & 105.33 \\
Player (ARW) & I & 3.63 & 6.08 & $7.08\left(^{*}\right)$ & 59.7 \\
Player (ALW) & I & 2.21 & 4.27 & $4.81\left(^{*}\right)$ & 62.70 \\
Player (ASS) & IV & 0.17 & -0.36 & 0.40 & 295.70 \\
\hline
\end{tabular}

\begin{tabular}{lccccc}
\hline Category & Quadrant & $\begin{array}{c}\text { Prospective } \\
\text { Perspective }\end{array}$ & $\begin{array}{c}\text { Retrospective } \\
\text { Perspective }\end{array}$ & Radius & Angle \\
\hline Player (AGKE) & III & -8.93 & -0.90 & $8.98\left(^{*}\right)$ & 185.74 \\
Player (ARB) & I & 4.33 & 4.13 & $5.99\left(^{*}\right)$ & 43.64 \\
Player (ALB) & I & 2.01 & 1.28 & $2.38\left(^{*}\right)$ & 32.53 \\
Player (ARCB) & I & 1.52 & 6.24 & $6.43\left(^{*}\right)$ & 76.29 \\
Player (ALCB) & II & -1.54 & 7.98 & $8.13\left(^{*}\right)$ & 100.94 \\
Player (ALMF) & II & -0.05 & 7.76 & $7.76\left(^{*}\right)$ & 90.35 \\
Player (ARW) & I & 12.49 & 3.92 & $13.09\left(^{*}\right)$ & 17.44 \\
Player (ALW) & I & 4.00 & 2.86 & $4.92\left(^{*}\right)$ & 35.52 \\
Player (ASS) & I & 7.30 & 4.57 & $8.61\left(^{*}\right)$ & 32.05 \\
Player (AF) & I & 10.52 & 3.09 & $10.96\left(^{*}\right)$ & 16.35
\end{tabular}

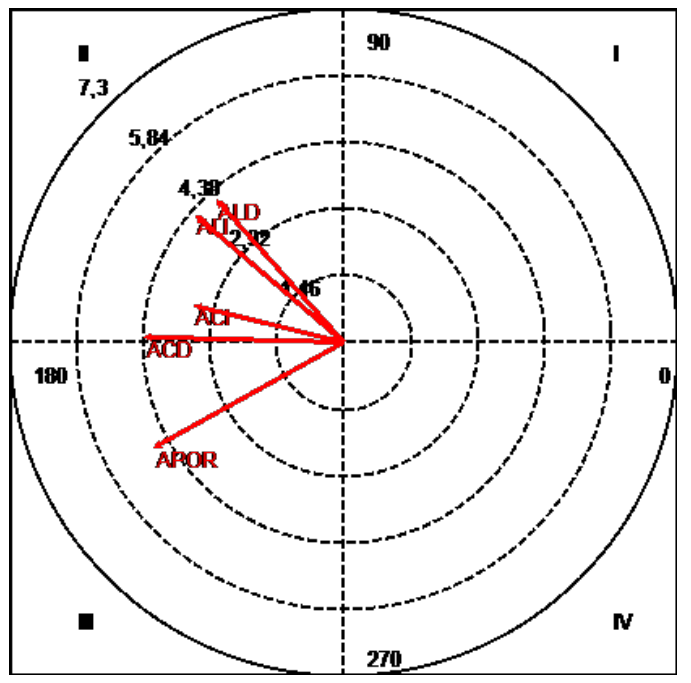


Díaz-Díaz, R.; Ramos-Verde, E. J.; García-Manso, J. M.; Valverde-Esteve, T.; Arriaza-Ardiles, E.

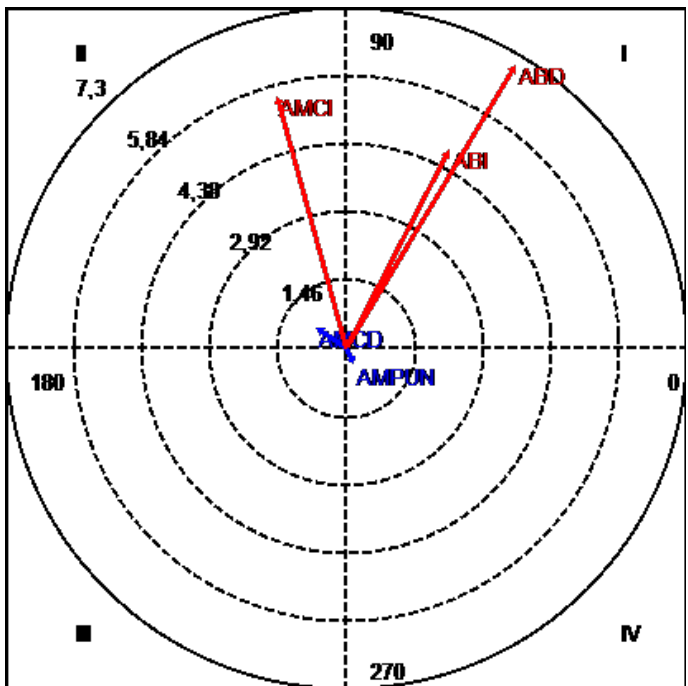

Figure 5. Graphic representation of the vectorial plane when we took the category (ACF) as focal behaviour for the other players of the team in the matches that ended in victory. On the left, the type of relationship of the reference player (ACF) and the most defensive players $(\mathrm{APOR}=$ goalkeeper; $\mathrm{ALI}=$ left-back; $\mathrm{ALD}=$ right-back; $\mathrm{ACD}=$ right centre-back; $\mathrm{ACI}=$ left centre-back). On the right, we can observe the relationships with the more attacking positions $(\mathrm{AMCD}=$ right midfielder; $\mathrm{AMCI}=$ left midfielder; $\mathrm{ABD}=$ right winger; $\mathrm{ABI}=$ left winger; $\mathrm{AMPUN}=$ second striker).

For the AF focal behaviour, the ALW and ARW players are located in quadrant I. Therefore, the relationship established between the wingers and the striker is of mutual activation. In quadrant II, players ARB, ALB, ARCB, ALCB and ALMF appear. The activation ratio of these players towards the AF player is therefore observed. There is only a relationship of inhibition with the AGKE player, located in quadrant III. As we have explained for the ASS player, the relationship between these cannot be considered a pattern of regular behaviour, as with the ARMF player.
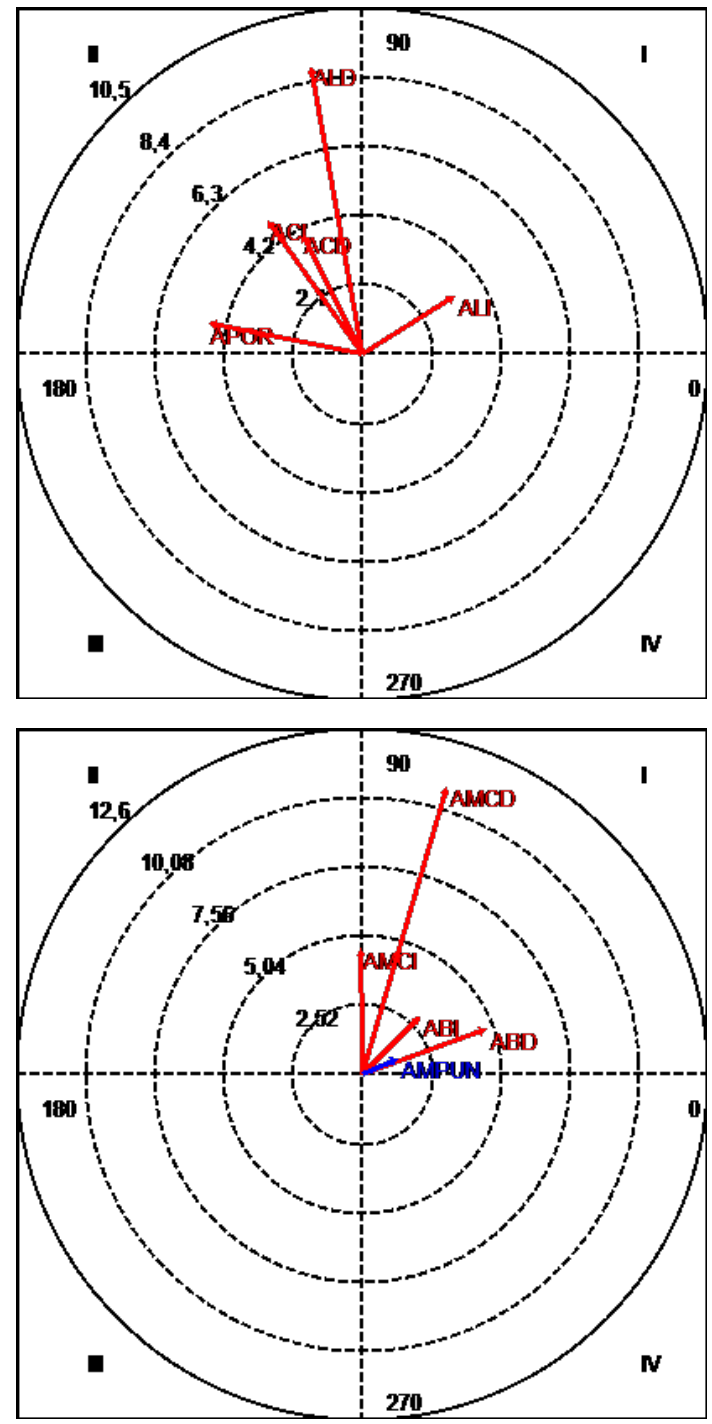

Figure 6. Graphic representation of the vectorial plane when we took the AF category as focal behaviour for the other players of the team in the matches that ended in a drawn. On the left, the type of relationship of the reference player $(\mathrm{APUN}=\mathrm{AF})$ and the most defensive players (APOR= goalkeeper; $\mathrm{ALI}=$ left-back; $\mathrm{ALD}=$ right-back; $\mathrm{ACD}=$ right centre-back; $\mathrm{ACI}=$ left centre-back) are shown. On the right, note the relationships with the more attacking positions $(\mathrm{AMCD}=$ right midfielder; $\mathrm{AMCI}=1$ left midfielder; $\mathrm{ABD}=$ right winger; $\mathrm{ABI}=$ left winger; $\mathrm{AMPUN}=$ second striker).

For the AF focal behaviour, the ALB, ALW, ARW and ARMF players appear in quadrant I, with the latter being the most important player in the retrospective plane. A random type relationship with the ACF player appears in this same quadrant, confirming the results obtained in the study of the 
The use of Polar Coordinates in the analysis of motor interaction in football according to the result.

previous interactions of this player. In quadrant II, the AGKE, ARB, ARCB and ALCB players appear as conditioned behaviours. There is therefore a relationship of activation of the player taken as conditioned behaviour towards the player taken as focal behaviour, considering these as regular patterns of behaviour. As shown in the graphs, mutually inhibiting relationships do not appear, and neither is there activation of the player taken as a focal category towards other players.

\section{DISCUSIÓN}

The objective of this study was analysed characteristics of interactions two players who we've considerated like the most representative in one Spanish team of second division A ((right midfielder and centre forward), taken into account the result of the match. (won or not won).

The empirical evidence suggests that the contextual variables that most influence football performance match are the location, the score and opponent's level (Lago, Casáis, Domínguez, Lago $\&$ Rey, 2009). Considering the score or result as a variable that determines the performance, this recognizes the possibility that the strategic behavior varies, not only from one match to another, but also within the same match.

In those matches who finished with a favorable score, it had been observed a real net of interactions from ARMF player to ALCB, ALMF y ASS players. When we analysed the diadics relations ships that stablished between the aforamentioned ARMF taken as focal behaviour and the other players taken as conditional behaviour, a clear relationship of mutual activation with spatially close players is appreciated.

The characteristics of these connection networks about (ARMF) change substantially when the result of the match is not as desired. In this second case, the interaction network is more powerful and rich, generating a wider and different reciprocal interaction network between the aforementioned ARMF player and the other team members, with a special relationship towards the players that occupy the positions of ARB, ALB, ARCB, ARW, ALW, ASS and AF. Taylor, Mellalieu, James \& Shearer, (2008) point out that variation in technical-tactical behaviors may have a certain relationship with the teams' strategy.

It must be taken into account that when the result is unfavourable (in our case, a draw at home), the players try to create tactical and strategic behaviours that allow them to control the ball (Bloomfield et al., 2005; Taylor et al., 2008; Lago \& Dellal, 2010; Collet, 2012; Castellano, 2018) and that take them to more offensive positions occupied by the players who are usually responsible for scoring the goal: ASS and AF. Such differences, the interactions of the ARMF in the matches that ended in a draw, show that the strategic behaviour varies noticeably not only from one match to another, but also according to the result. On these occasions, such players participate more in the game and connect with more areas to move the ball more and surprise the opposite team's defenders more easily. For this, it is also necessary to have a close relationship with the ALMF, which happens in this case if we check the value of the retrospective relationship generated with this player. We must bear in mind that it is commonly accepted that midfielders are the key players when constructing the offensive game and preparing goal situations (Kannekens, Marije, Elferink-Gemser \& Visscher, 2009; Sarmento, Anguera, Campaniço \& Leitao, 2010; Kannekens, Marije, Elferink-Gemser \& Visscher, 2011; Robles, Castellano \& Perea, 2014; Maneiro-Dios $\&$ Amatria, 2018). In our case, the ARMF in these games distributes a significant amount of balls to the midfielder on the opposite side, supposedly in order to change the direction of the game, which is not as common when possession is not so important for the team, when they may give their possession to the other team because they are ahead on the scoreboard.

When there is ample possession of the ball, a tactical organization is created where the circulation of the ball arrives fluidly, efficiently 
Díaz-Díaz, R.; Ramos-Verde, E. J.; García-Manso, J. M.; Valverde-Esteve, T.; Arriaza-Ardiles, E.

and frequently at the usual areas from which to shoot, which are usually occupied by the top players (Kempe \& Memmert, 2018). The aforementioned authors, after studying the Football FIFA World Cup of 2010 and 2014, found that the closer the actions that generated an opportunity to shoot at goal, the more creative they were. This situation occurred more frequently among the teams that reached the last rounds of the tournament, which were the teams that showed the most creativity in their game. The high creativity of the last two previous actions to the shots at goal seems to be the fundamental factor that allows us to explain the effectiveness against the opponent's goal. As a general rule, in a well-organized team, it is the central midfielders (especially the playmakers, or creative midfielders) that manage to establish mutually activating relationships, that is to say in both planes, or in the prospective plane with the wingers and forwards (Robles et al., 2014; Clemente et al, 2014). In our case, this is also reflected in the analysis of the interactions (type and quantity) in which the centre forward participates. In the matches with a favourable result, the AS is a clear receiver of a significant number of balls with which to try to score. They only create bidirectional interactions with the two wingers. This type of behaviour is totally different in the matches in which the score is not in their favour. As can be observed in table 6 and figure 5 , the AF continues to receive a significant number of balls and interacts more frequently with other teammates (ALB, ARMF, ARW, ALW and AS).

Within the limitations of the study we must indicate that the evaluated team only did it when acting as a local. Taking into account the interactive nature of the situational variables (Lago et. al 2010), we must be cautious when interpreting the results of the study. On the other hand, for a deeper knowledge and analysis, matches could be divided into moments of play, depending on the variations of the marker (Blommfield et al., 2005, Dennis \& Carron, 1999, Tucker et al., 2005).

\section{CONCLUSIONS}

The use of Polar Coordinates analysis allows us to analyze and evaluate the number and types of offensive interactions that occur during the game, giving us relevant and meaningful information about what happens in the game. In this study we show that the relationship between RMF and $F$ in those matches which ended in draw or lose is much bigger than those matches ending in victory. Moreover, not only between these two players already mentioned but also between the RMF and the rest of the players.

\section{PRACTICAL IMPLICATIONS}

Through the analysis of Polar Coordinates, you can establish dual character relationships that asociated two situationals variables as the location and the final result allow us to access the most important information that has happened during the game.

Knowing the regularities or regular patterns in the dual interactions will enable us to make changes that alter the tactical behaviour and the effectiveness of the actions, and even address the actions of the rivals that could be altering our attack game. We understand that polar coordinates analysis can be a complementary tool that helps game analysts to provide decisive information to the coach with which to evaluate the game in real time or to propose tactical solutions to develop during training.

\section{REFERENCES}

1. Almeida, C. H., Duarte, R., Volossovitch, A., \& Ferreira, AP. (2016). Scoring mode and age-related effects on youth soccer teams' defensive performance during small-sided games. Journal of Sports Sciences. $\quad 34(14), \quad$ 1355-1362 https://doi.org/10.1080/02640414.2016.11 50602 
The use of Polar Coordinates in the analysis of motor interaction in football according to the result.

2. Anguera, M. T. (1997). Complementariedad de análisis en los diseños LAG-LOG. En V Congreso de Metodología de las CC. Humanas y Sociales. Sevilla: AEMCCO. 23-26 de septiembre.

3. Anguera, M. T., Blanco-Villaseñor, A., Hernández-Mendo, A., \& Losada, J. L. (2011). Diseños observacionales: ajuste y aplicación en psicología del deporte. Cuadernos de Psicología del Deporte, 11(2), 63-76.

4. Anguera, M. T., \& Hernández-Mendo, A. (2015). Técnicas de análisis en estudios observacionales en ciencias del deporte. Cuadernos de Psicología del Deporte, 15(1), 13-30.

https://doi.org/10.4321/S1578-

$\underline{84232015000100002}$

5. Barreira, D., Garganta, J., Castellano, J., Machado, J., \& Anguera, M. T. (2015). How elite-level soccer dynamics has evolved over the last three decades? Input from generalizability theory. Cuadernos de Psicología del Deporte, 15, 51-62. https://doi.org/10.4321/S1578-

84232015000100005

6. Blommfield, J. R., Polman, R. C., \& O'Donoghue, P. G. (2005). Effects of score-line on team strategies in FA Premier League Soccer. Journal of Sports Sciences, 23, 192-193.

7. Castañer, M., Barreira, D., Camerino, O. Anguera, M. T., Fernandes, T., \& Hileno, R. (2017). Mastery in Goal Scoring, TPattern Detection, and Polar Coordinate Analysis of Motor Skills Used by Lionel Messi and Cristiano Ronaldo. Frontiers inPsychology, 8. https://doi.org/10.3389/fpsyg.2017.0074 $\underline{1 .}$

8. Castellano, J., \& Hernández-Mendo, A (2002). Aportaciones del análisis de coordenadas polares en la descripción de las transformaciones de los contextos de interacción defensivos en fútbol.

Kronos 1(1), 42- 48. Recuperado en http://www.revistakronos.com/docs/File/k ronos $/ 1 /$ kronos 16 6.pdf.

9. Castellano J., \& Hernández-Mendo A. (2003). El análisis de coordenadas polares para la estimación de relaciones en la interacción motriz en fútbol. Psicothema, 15(4), 569-574.

10. Castellano, J., Hernández-Mendo, A., Morales-Sánchez, V., \& Anguera, M. T. (2007). Optimising a probabilistic model of the development of play in soccer. Quality \& Quantity, 41(1), 93- 104. https://doi.org/10.1007/s1135-005-3148-0

11. Castellano, J., Álvarez-Pastor, D., \& Blanco-Villaseñor, Á. (2013). Análisis del espacio de interacción en fútbol. Revista de Psicología del Deporte, 22(2), 437-446.

12. Castellano, J. (2018). Relación entre indicadores de rendimiento y el éxito en el fútbol profesional. Revista Iberoamericana de Psicología del ejercicio y el Deporte, 13(1), 41-49.

13. Clemente, F. M., Martins, M. L., Couceiro, M. S., Mendes, R. S., \& Figueiredo, A. J. (2014). A network approach to characterize the teammates' interactions on football : A single match analysis. Cuadernos de Psicología del Deporte, 14(3), 141-148. https://doi.org/10.4321/S157884232014000300015.

14. Cohen, J. (1960). A coefficient of agreement for nominal scales. Educational and Psichological Measurement, 41, 687699.

https://doi.org/10.1177/001316446002000 104

15. Collet, C. (2012). The possession game? A comparative analysis of ball retention and team success in European and international football, 2007-2010. Journal of Sports Sciences, $\quad 31(2), \quad$ 123-136. 
Díaz-Díaz, R.; Ramos-Verde, E. J.; García-Manso, J. M.; Valverde-Esteve, T.; Arriaza-Ardiles, E.

https://doi.org/10.1080/02640414.2012.72 7455.

16. Díaz-Díaz, R., Hernández-Moreno, J. \& Hernández-Flores, C.N. (2016). Análisis de las interacciones motrices en fútbol a través de coordenadas polares. Acción Motriz, 16, 27-36.

17. Echeazarra-Escudero, I., CastellanoPaulis, J., Usabiaga-Arruabarrena, O. y Hernández-Mendo, A. (2015). Diferencias en el uso estratégico del espacio en categorías infantil y cadete de fútbol: una aplicación del análisis de coordenadas polares. Cuadernos de Psicología del Deporte, 15(1), 169-180.

18. Fernández-Hermógenes, D., Camerino, O., \& García de Alcaraz, A. (2017). Setpiece offensive plays in soccer. Apunts. Educación Física y Deportes, 129, 78-94. https://doi.org/10.5672/apunts.20140983.es.(2017/3).129.06

19. Fernandez-Navarro, J., Fradua, L., Zubillaga, A., Ford, P.R., \& McRobert, A. P. (2016). Attacking and defensive styles of play in soccer: analysis of Spanish and English elite teams. Journal of Sports Sciences. 34(24), 2195-2204. https://doi.org/10.1080/02640414.2016.1169309

20. Gabín, B., Camerino, O., Anguera, M. T., \& Castañer, M. (2012). Lince multiplatform sport Analysis software. Procedia - Social and Behavioral Sciences (46), 4692-4694. DOI: https://doi.org/10.1016/j.sbspro.2012.06.320.

21. Glazier, P. S., \& Robins, M. T. (2013). Selforganisation and constraints in sports performance. In McGarry, T., O'Donoghue, P., \& Sampaio, J. (Eds.), Routledge handbook of sports performance analysis 42-51. London: Routledge.

22. Grehaigne, J. F., Bouthier, D., \& David, B. (1997). Dynamic-system analysis of opponent relationships in collective actions in soccer. Journal of Sports Sciences, 15(2), 137-149. https://doi.org/10.1080/026404197367416.

23. Hernández-Mendo, A. y Anguera, M. T. (1999). Aportaciones de análisis de coordenadas polares a los deportes de equipo.
En Félix Guillén García, La Psicología del Deporte en España al final del Milenio 169175. Las Palmas de Gran Canaria: Servicio de Publicaciones y Producción Documental de la Universidad de Las Palmas de Gran Canaria.

24. Hernández-Mendo, A., López-López, J. A., Castellano, J., Morales-Sánchez, V., \& Pastrana, J.L. (2012). HOISAN 1.2: Programa informático para uso en metodología observacional. Cuadernos de Psicología del Deporte, 12(1), 55

78.https://doi.org/10.4321/S157884232012000100006.

25. Kannekens, R., Marije T., Elferink-Gemser., Visscher, C. (2009). Tactical skills of world-class youth soccer teams. Journal of Sports Sciences, 27(8), 807-812. https://doi.org/10.1080/026404109028943 $\underline{39 .}$

26. Kannekens, R., Marije, T., Elferink- Gemser., \& Visscher. C. (2011). Positioning and deciding: key factors for talent development in soccer. Scandinavian Journal of Medicine \& Science in Sports 21(6), 846-852. https://doi.org/10.1111/j.16000838.2010.01104.x

27. Kempe, M., \& Memmert, D. (2018). "Good, better, creative" the influence of creativity on goal scoring in elite soccer. Journal of Sports Sciences, 1-5.

https://doi.org/10.1080/02640414.2018.1459 153

28. Lago, C., \& Anguera, M. T. (2002). Use of the polar coordinates technique to study interactions among professional Soccer players. Revista Portuguesa de Ciências do Desporto, 2(4), 21-40. https://doi.org/10.5628/rpcd.02.04.21

29. Lago, C., \& Martin, R. (2007). Determinants of possession of the ball in soccer. Journal of Sports Sciences, 25(9), 969-974. https://doi.org/10.1080/02640410600944626

30. Lago, C.; Casáis, L.; Domínguez, E.; Lago, J.; Rey, E. (2009). Influencia de las variables contextuales en el rendimiento físico en el 
The use of Polar Coordinates in the analysis of motor interaction in football according to the result.

fútbol de alto nivel. Motricidad.

European Journal of Human Movement, 23, 95-106.

31. Lago, C.; Casáis, L.; Domínguez, E.; Martín, R.; Seirul-lo, F. (2010). La influencia de la localización del partido, el nivel del oponente y el marcador en la posesión del balón en el fútbol de alto nivel. Apunts. Educación Física y Deportes N. ${ }^{\circ} 102,4^{\circ}$ trimestre, pp. 78-86.

32. Lago, C., \& Dellal, A. (2010). Ball Possession Strategies in Elite Soccer According to the Evolution of the Match-Score: the Influence of Situational Variables. Journal of Human Kinetics, 25(1), 93-100. https://doi.org/10.2478/v10078-010-0036-z

33. Lames, M., \& McGarry, T. (2007). On the search for reliable performance indicators in game sports. Internacional Journal of Performance Analysis in Sport, 7(1), 62-79. https://doi.org/10.1080/24748668.2007.1186 $\underline{8388}$

34. López-López; J.A., Menescardi, C., Estevan, I., Falcó, C. y Hernández-Mendo, A. (2015). Análisis técnico-táctico en Taekwondo con coordenadas polares a través del software HOISAN. Cuadernos de Psicología del Deporte, 15(1), 131 -142.

35. Maneiro-Dios, R., \& Amatria, M. (2018) Polar Coordinate Analysis of Relationships With Teammates, Areas of the Pitch, and Dynamic Play in Soccer: A Study of Xabi Alonso. Frontiers in Psychology, 9, DOI: https://doi.org/10.3389/fpsyg.2018.00389.

36. Martín-González J.M., Díaz-Díaz R., Ramos, E., Arriaza, E., Da Silva-Grigoletto M.E., \& García-Manso J.M. (2017). Topological properties and dynamics of nets game shown by France and Portugal in the final of European Cup soccer 2016. Motricidade, 13(S1): 101-112. Performance Analysis in Sport,18(1), 151-167, DOI:10.1080/24748668.2018.1460052

37. Morillo-Baro, J. P., Reigal, R. E., HernándezMendo, A. (2015) Análisis del ataque posicional de balonmano playa masculino y femenino mediante coordenadas polares. RICYDE. Revista Internacional de Ciencias del Deporte, 11(41),226-

244. http://dx.doi.org/10.5232/ricyde 2015.04103

38. Morillo, J.P., Reigal, R.E., Hernández-Mendo, A., Montaña, A. and Morales-Sánchez, V. (2017) Decision-Making by Handball Referees: Design of an ad hoc Observation Instrument and Polar Coordinate Analysis. Front. Psychol., $\quad 20 \quad$ October 2017| https://doi.org/10.3389/fpsyg.2017.018 $\underline{42}$

39. Moura, F. A., Santana, J. E., Vieira, N. A., Santiago, R. P., \& Cunha, S. A. (2015). Analysis of soccer players' positional variability during the 2012 UEFA European Championship: a case study. Journal of Human Kinetics, 47(1), 225-236. https://doi.org/10.1515/hukin-2015-0078

40. Munroe, K., Estabrooks, P., Dennis, P. \& Carron A. (1999). Phenomenological Analysis of Group Norms in Sport Teams. Human Kinetics Journal. 13(2), 171-182. https://doi.org/10.1123/tsp.13.2.171

41. Navarro, A., Morillo, J. P., Reigal, R. E. \& Hernández-Mendo, A. (2018) Polar coordinate analysis in the study of positional attacks in beach handball, International Journal of Performance Analysis in Sport, 18(1), 151-167, DOI:10.1080/24748668.2018.1460052

42. Perea, A., Castellano, J., Alday, L., \& Hernández-Mendo, A. (2012). Analysis of behaviour in sports through Polar Coordinate Analysis with MATLAB. Quality \& Quantity, 46(4), 1249-1260. https://doi.org/10.1007/s11135-011-9435-z

43. Pollard, R., \& Pollard, G. (2005). Long-term trends in home advantage in professional team sports in North America and England (18762003). Journal of sports sciences, 23(4), 337- 
Díaz-Díaz, R.; Ramos-Verde, E. J.; García-Manso, J. M.; Valverde-Esteve, T.; Arriaza-Ardiles, E.

350.

https://doi.org/10.1080/02640410400021559

44. Quera, V., Bakeman, R., \& Gnisci, A. (2007). Observer agreement for event sequences: Methods and software for sequence alignment and reliability estimates. Behavior Research Methods, 39(1), 39-49. https://doi.org/10.3758/BF03192842

45. Riveiro-Bozada, A., García-García, O., Serrano-Gómez,V., Morales-Sánchez, V., López-López, J. A. y Hernández-Mendo, A. (2016).Influencia del nivel de competición en las acciones técnicas de punto realizadas en Shiai Kumite femenino de karate. Análisis de coordenadas polares. Cuadernos de Psicología del Deporte, 16(1), 51-68.

46. Robles, F. J., Castellano, J., \& Perea, A. E. (2014). Differences of the game between the football spanish team and its rivals. Revista. Iberoamericana de Ciencias de la Actividad. Fisica y el Deporte. 3(2), 1-8.

47. Ruiz de Oña, M., (2018). La mirada del psicólogo: 21 años de experiencia en el Athletic Club de Bilbao. Revista de Psicología Aplicada al Deporte y al Ejercicio Físico (2018), 3, e6, 1-1.

48. Sackett, G.P. (1980). Lag Sequential Analysis as a data Reduction Technique in Social Interaction Research. En D.B. Sawin, R.C. Hawkins, L.O. Walker y J.H. Penticuff (Eds.), Excep-tional infant. Phychosocial risks in infant-environment transactions (pp. 300340). New York: Brunner/Mazel.

49. Sánchez-Flores, J., Martín-González, J.M., García-Manso, J.M., De Saa, Y., ArriazaArdiles, E.J., \& Da Silva-Griglotetto, M.E. (2016). Análisis de los goles conseguidos en 13 temporadas (2000/01-2012/13) correspondientes a la Primera División de la Liga Española de Fútbol Profesional. Revista Andaluza de Medicina del Deporte, 9(2),55$\underline{61 .}$

https://doi.org/10.1016/j.ramd.2015.05.006

50. Sampaio, J., Macas, V. (2012). Measuring tactical behaviour in football. Internacional
Journal of Sports Medicine, 33(5), 395-401. https://doi.org/10.1055/s-0031-1301320

51. Sarmento, H., Anguera, M. T., Campaniço, J., \& Leitao, J. (2010). Development and validation of a notational system to study the offensive process in football. Medicina (Kaunas), 46(6), 401-407. https://doi.org/10.3390/medicina46060056

52. Seabra, F., \& Dantas, L. E. (2006). Space definition for match analysis in soccer. International Journal of Performance Analysis in Sport, 6(2), 97-113. https://doi.org/10.1080/24748668.2006.11 868376

53. Sousa, D. J., Prudente, J. N., Sequeira, P., López López, J. A. y Hernández-Mendo, A. (2015). Análisis de las situaciones de juego 2vs2 en el campeonato europeo masculino de balonmano 2012: Aplicación de la técnica de coordenadas polares. Cuadernos de Psicología del Deporte, 15(1), 181 -194.

54. Staufenbiel, K., Lobinger, B., \& Strauss, B. (2015). Home advantage in soccer-A matter of expectations, goal setting and tactical decisions of coaches? Journal of sports sciences, 33(18), 1932-1941. https://doi.org/10.1080/02640414.2015.10189 29

55. Taleb, N. N. (second edition). (2010). The Black Swan: The Impact of the Highly Improbable. London: Penguin.

56. Tassi, J.M., Rivera, S., \& Morilla, M. (2018). El entrenamiento Psicológico-integrado en fútbol a través de tareas de entrenamiento. Revista de Psicología Aplicada al Deporte y al Ejercicio Físico, 3(1), E51-15. https://doi.org/10.5093/rpadef2018a4

57. Taylor, J. B., Mellalieu, S. D., James, N., \& Shearer, D. (2008). The influence of match location, qualify of opposition and match status on technical performance in professional association football. Journal of Sports Sciences, 26(9), 885-895. https://doi.org/10.1080/02640410701836887 
The use of Polar Coordinates in the analysis of motor interaction in football according to the result.

58. Tenga, A., Holme, I., Ronglan, L. T., \& Bahr, R. (2010a). Effect of playing tactics on achieving score-box possessions in a random series of team possessions from Norwegian professional soccer matches. Journal of Sports Sciences, 28(3), 245-255. https://doi.org/10.1080/02640410903502766

59. Tenga, A., Ronglan, L. T., \& Bahr, R. (2010b). Measuring the effectiveness of offensive match-play in professional soccer. European Journal of Sport Sciences, 10(4), 269-277. https://doi.org/10.1080/17461390903515170

60. Tucker, W., Mellalieu, S., James, N. \& Taylor, J. (2005). Game Location Effects in Professional Soccer: A Case Study. $5(2)$. 23-35. https://doi.org/10.1080/24748668.2005.1186 $\underline{8325}$ 